\title{
Stylistic Analysis for the EFL Classroom
}

\author{
Todd Hull* \\ Assistant Professor, Department of English, Hankuk University of Foreign Studies, Seoul, South Korea \\ *Corresponding Author: Todd Hull, Assistant Professor, Department of English, Hankuk University of \\ Foreign Studies, Seoul, South Korea
}

\begin{abstract}
Literature can be both used and useful in foreign language classrooms. Sometimes the objective is incidental learning, where learner enjoyment of the work is foremost, and where the contention is that learners acquire language incidentally while enjoying a work of literature, as is the case with extensive reading. Other times the goal is more deliberate learning where there is a conscious focus on language teaching, as when a specific language point from the text is highlighted and practiced. One type of deliberate learning which is not as much utilized in the EFL context as other methods is literary stylistics. Stylistic analysis focuses on the linguistic mechanics of a text (primarily at the lexical, phonological, grammatical, and discourse levels) not primarily as a means to give form-focused instruction in any of those areas but as a means to enhance appreciation of a work of literature by understanding how the work achieves its overall communicative effect (though foreign language competence can improve in a stylistic analysis). This paper will describe what stylistics is, give a short example of a stylistic analysis of a text, an excerpt from Charles Dickens' Bleak House, and then discuss how stylistics can be used in the EFL classroom.
\end{abstract}

Keywords: Stylistic Analysis; Stylistics; Practical Stylistics, Literature in EFL Classrooms; Lexical Analysis; Phonological Analysis; Grammatical Analysis; Discourse Analysis; Incidental Learning; Deliberate Learning

\section{INTRODUCTION}

Literature is not just an endeavor of the soul. It can be a feature of the classroom-and not only the traditional classroom, but the EFL classroom as well. How educators would like students to view literature in the EFL context, though, varies from teacher to teacher. For practitioners of extensive reading and advocates of reading as a primary means of language acquisition (Krashen 1982), the ideal situation is for learners to be reading for the sake of enjoyment-not because they have an assignment for their foreign language class. The desire here is for learners to consciously enjoy a piece of reading and subconsciously acquire language along the way. The focus in this approach is on incidental rather than deliberate learning (Nation 2014), with incidental learning defined by Hull (2019) as "the kind that happens subconsciously, for example, during extensive reading when language is encountered and cognitively processed at the subconscious level in various ways."

However, some research has shown that many learners view literature in the classroom as a tool for learning the language they are studying rather than purely an endeavor of pleasure. This is not necessarily a bad thing, according to a study of Dutch secondary school students who had positive views of literature in the EFL classroom for the explicit purpose of facilitating language ability (Bloemert, Paran, Jansen, \& van de Grift 2019). This is good news for educators like Calafato and Paran (2019) who note that literature became less used in the classroom in the mid twentieth century but has made a recent comeback, much to the benefit, in their view, of both students and teachers, a view which this paper shares.

\section{How Literature has BeEN USED IN EFL CONTEXTS}

Literature is used in EFL classrooms to a variety of ends and through either or both deliberate and incidental learning. Exposing learners to great works of creative genius is one goal. Using literature in a foreign language as content-based instruction to develop learners' language competency through traditional literary analysis, e.g. analyzing it for its themes, symbolism, historical references, literary style, etc. is another. In both of these, abilities in the target language are enhanced through incidental learning. Other teachers wish to further learners' proficiency in a foreign language through deliberate 
attention to the language of the text. Deliberate learning has been around a lot longer as an explicit means of furthering foreign language ability than has incidental learning and, despite a contemporary bias against it (Krashen 1982, Pienemann 2012, Lightbown and Spada 2013), is still supported in at least some form by a large number of scholars (Nation 2013, Ellis 2003 and 2005, and Celce-Murcia 2002) as well as a majority of classroom instructors. Deliberate learning with relation to literature in a foreign language context often takes the form of character analysis, plot dissection, attention to overarching themes of the work, and so on.

\section{LITERARY STYLISTICS}

One type of deliberate learning that is underutilized in the EFL classroom is literary stylistics. Literary stylistics incorporates literature into the EFL curriculum, but adds another level of analysis to texts, which complements (not replaces) traditional literary analysis, one in which prominent linguistic features of a text are analyzed to see if they contribute to an interpretation of the text, add to its communicative effect, and deepen readers' appreciation of a work. Since literature is composed of language, concentrating on it can be fruitful. "The basic assumption is that literature is made from and with language, that language is the medium of literature and that beginning with the very textuality of the text is a secure foundation for its interpretation." (Carter 2010) "Stylistics...makes language explicit and interprets how information has been arranged within a text using various stylistic and rhetorical devices." (Amir 2018) It is "the direct application of linguistic evidence to interpret and analyze literature, and is a general analytical tool that uses explanations of formal aspects of a poem [or other piece of literature] to discuss meaning." (Kellem 2009)

\subsection{Literary Stylistics as Complement to Traditional Analysis}

As mentioned above, despite the claims of a small minority of its proponents, stylistic analysis is not a replacement for traditional analysis. Instead, it is a complementary endeavor. Widdowson (1972) disagrees with "a tendency for linguists who have concerned themselves with literary texts to suggest that an analysis in terms of the theoretical units of descriptive linguistics yields information of an intrinsically more essential kind than that which results from the impressionistic approach of the literary scholar." Sinclair (1982) argues that "the teaching of command of a language...cannot be adequately informed by separate development of the accepted approaches of language and literature, but only by integration." Stylistics and traditional analysis go hand in hand.

\subsection{Highlighting Language Addresses a Major Weakness in Traditional Analysis}

Stylistics does not just complement traditional literary analysis, though. It strengthens it by addressing one of its major weaknesses: the idea that how literature — especially poetry - uses language is just a way of enhancing some central idea that the work is "really" about. This is not the case. The way language is used is a central feature of literature, on par with "bigger" ideas such as the overall themes of a work and what that work "means." Zapruder (2019) states that a central question is:

Why would someone make a poem in the first place? Obviously it's because what they have to say...you cannot say it in prose. That's the only reason to write a poem...a poem does things that no other use of language can do...it is a way of making connections [between] ideas and thoughts and images that we don't usually put together. Those things can be put together in a poem in a way that makes new meaning.

So language is not just some "icing on the cake." It is at the very core of how literature does what prose cannot.

With reference to poetry, Zapruder (2017) contrasts himself with traditional literary critics like Harold Bloom who say that understanding literature begins with knowing what its allusions are, with knowing what historical events or other works of literature are referred to in a particular work. "This is not true," says Zapruder. "The art of reading poetry does not begin (emphasis in original) with thinking about other cultural products, or historical moments, or great philosophies. It begins with reading the words of a poem."

Stylistics highlights and values this unique aspect of literature by focusing on how language makes it impactful and emphasizing the fact that literature cannot be literature without its special use of language. 


\section{Henry Widdowson's Practical Stylistics}

The central figure in developing practical stylistics is Henry Widdowson, whose seminal 1975 and 1992 books, Stylistics and the Teaching of Literature and Practical Stylistics have become the blueprint for much of stylistics as it is practiced today. Widdowson says that traditionally students of literature were expected to be "animators" of texts rather than "authors." With traditional literary analysis, "the reader is cast in a subservient and submissive role: the task is to discover the meanings which are immanent in the text." So

the reader can assume the role of animator, whose task is simply to activate meanings deemed to be in the text, but who takes no initiative to engage creatively with the text, [simply providing] an exegesis. As author, the reader provides an interpretation...Essentially, I argue that the experience of poetry, and its educational relevance, depend on the reader assuming an author role. (Widdowson 1992)

In engaging with literary stylistics, students of literature become "authors" in their own right, discarding the passive role of interpreters of a text and taking on the active role of providing their own perspectives. But - and this is emphasized strongly by practitioners of stylistics - this must always, always be based assiduously on actual textual evidence. It should never entail unsubstantiated, intuitive flights of fancy. As Widdowson states, it requires of students a "justifying [of] their own judgement by making as precise reference to the text as possible."

\section{THE BENEFITS OF STYLISTIC ANALYSIS FOR EFL LEARNERS}

In addition to empowering students in general to give their own interpretations of literary works, stylistics is beneficial for EFL learners because it also gives learners concrete aspects of the text to focus on, rather than the difficult, and often arcane endeavor of attempting to extract symbolism, historical references and other aspects of traditional literary analysis, endeavors which, while certainly worthy, can be off-putting for many students, second languages learners in particular. "The animator role...requires a great deal of special expertise. Exegesis is an elite and privileged activity, reserved for such people as scholars and priests." (Widdowson 1992)

Rosenkjar (2006) sums up the ennui and even antagonism to literature felt by a wide swath of the public when he quotes a Japanese university student whose interest in literature was stifled by how it was traditionally taught: "I did not like Japanese literature...the class was not interesting to me...because tutors only emphasized to memorize important points. Studying English literature ...was not much better. We always studied them by translating them into Japanese first, so I never appreciated English literature as they are."

Stylistic analysis allows learners to engage works of literature in their original forms and empowers students uncover the wonders of how literary language creates the emotional effect that literature has on humans. Four levels of analysis are usually undertaken: 1) lexical, 2) phonological, 3) grammatical, and 4) discourse.

\section{LEVELS OF STYLISTIC ANALYSIS}

\subsection{Analysis at the Level of Lexis}

When learners analyze a text at the lexical level, they look for features like repetition, neologisms, words used as parts of speech different from how they usually occur (a noun being used as a verb, for example), connotations, and lexical sets in which words can be grouped according to a central theme (and if there are multiple lexical sets, do they complement or contrast with one another). Are there prominent collocations? Do some lexical items have multiple meanings each of which might contribute to the effect of the text? In looking at these aspects and others, learners can highlight the effect of specific words the author has chosen on the overall feeling of the work.

\subsection{Analysis at the Level of Phonology}

At the phonological level are features, many of which figure in traditional analysis, such as consonance, assonance, alliteration, onomatopoeia, rhyme, and meter. Stylistics puts extra emphasis on how these "mechanical" features of the text work in concert (or in competition-or both) to accentuate and, as Zapruder stresses, indeed help to create, the effect of the text. They are not just noted as features of the work, but are analyzed for how they invoke feelings in the reader that literature uniquely brings about. 


\subsection{Analysis at the Level of Grammar}

The grammatical aspects of a literary text less frequently enter traditional literary analyses. But they can be quite profitable and thus play a prominent role in stylistic analysis. Is there any non-standard grammar and how does it contribute? Is there grammatical ambiguity? Are there any patterns in the grammar of the text? Are sentences single or multi-clause constructions? Does the structure of the text mirror or contrast with the structure of the sentences that comprise it? Are clauses interrogative, imperative, or exclamatory? Are they transitive or intransitive? Are there unusual features of punctuation? These are some of the grammatical aspects of a text that can be explicated in an analysis of their influence on the overall effect of the text.

\subsection{Analysis at the Level of Discourse}

At the level of discourse, learners consider aspects of overarching features of the entire text like voice (first person, etc.), cultural allusions and contexts, its orientation in time and space, and finally, what ideological perspective the author might be coming from, "the set of values, or belief system, communicated by the language of the text." (Widdowson 1975) And again, how do these work with or against each other to contribute to the work's unique effect?

\section{A Short (and incomplete) Stylistic Analysis of the Opening of Charles Dickens' BLEAK HOUSE}

One excerpt of text in which stylistic analysis has brought out previously unexplored aspects is the opening of the novel Bleak House, by Charles Dickens, who is enjoying a bit of a renaissance as his works are being looked at not just for their social and political commentary, but also for their considerable skill and craftsmanship, leading him to be labeled by some a "master stylist." Bleak House opens thus:

London. Michaelmas Term lately over, and the Lord Chancellor sitting in Lincoln's Inn Hall. Implacable November weather. As much mud in the streets, as if the waters had but newly retired from the face of the earth, and it would not be wonderful to meet a Megalosaurus, forty feet long or so, waddling like an elephantine lizard up Holborn Hill. Smoke lowering down from chimneypots, making a soft black drizzle with flakes of soot in it as big as full grown snowflakes - gone into mourning, one might imagine, for the death of the sun. Dogs, undistinguishable in the mire. Horses, scarcely better; splashed to their very blinkers. Foot passengers, jostling one another's umbrellas, in a general infection of ill-temper, and losing their foothold at streetcorners, where tens of thousands of other foot passengers have been slipping and sliding since the day broke (if this day ever broke) adding new deposits to the crust upon crust of mud, sticking at those points tenaciously to the pavement and accumulating at compound interest.

Fog everywhere. Fog up the river, where it flows among green aits and meadows; fog down the river, where it rolls defiled among the tiers of shipping, and the waterside pollution of a great (and dirty) city. Fog on the Essex Marshes, fog on the Kentish heights. Fog creeping into the cabooses of collier-brigs; fog lying out on the yards, and hovering in the rigging of great ships; fog drooping on the gunwales of barges and small boats. Fog in the eyes and throats of ancient Greenwich pensioners, wheezing by the firesides of their wards; fog in the stem and bowl of the afternoon pipe of the wrathful skipper, down in his close cabin; fog cruelly pinching the toes and fingers of his shivering little "prentice boy on deck. Chance of people on the bridges peeping over the parapets into a nether sky of fog, with fog all round them, as if they were up in a balloon, and hanging in the misty clouds.

Gas looming through the fog in divers places in the street, much as the sun may, from the spongey fields, be seen to loom by husbandman and ploughboy. Most of the shops lighted two hours before their time - as the gas seems to know, for it has a haggard and unwilling look.

The raw afternoon is rawest, and the dense fog is densest, and the muddy streets are muddiest, near that leaden-headed old obstruction, appropriate ornament for the threshold of leaden-headed old corporation: Temple Bar. And hard by Temple Bar, in Lincoln's Inn Hall, at the very heart of the fog, sits the Lord High Chancellor in his High Court of Chancery.

At the level of lexis, Carter (2010) says of this passage that a stylistic analysis "would need to take due account of the...role of verbs." He observes that the verbs "“waddling', 'splashed', 'jostling', 
'slipping', 'sliding'... all serve to create an atmosphere of constant action and movement in the big city." Metaphor can also figure into a lexical analysis and Dickens uses an unusual metaphor when he describes mud as "accumulating at compound interest."

Phonologically, Dickens makes liberal use of consonance, for example the copious repetition of the liquid lateral "l" in "waddling like an elephantine lizard up Holborn Hill." Alliteration occurs throughout the passage. "Fog creeping into the cabooses of collier-brigs" sees the repetition of the voiceless velar stop $/ \mathrm{k} /$ at the beginnings of the words creeping, cabooses, and collier. Assonance is seen in phrasings such as "threshold of leaden-headed old corporation."

A prominent grammatical feature that Carter points out is an absence of finite verbs in main clauses. "Main finite verbs provide... a kind of anchor for the action. It is clear when something took place and that the action was completed." With no finite verbs in main clauses, "the reader is left suspended, knowing that the action is ongoing, but awaiting a main verb to give you your bearings."

At the discourse level, it can be argued that each of the first three paragraphs revolves around a central "theme": mud, fog, and gas respectively. The structure of the paragraphs mirrors the sentence structure that comprises them. Paragraphs are in the form of topic-modification and sentences are in the form of noun-modification.

These are only some of the linguistic features of this passage that a stylistic analysis can highlight, complementing components of traditional literary analysis, and making their own contributions to how the language of the text creates literary effect. These lexical, phonological, grammatical, and discourse features highlight Dickens' characterization in his novels of cities, especially London, as grim, squalid, impoverished, dysfunctional, dystopian pools of putrefaction that later spawned the eponymous adjective, "Dickensian."

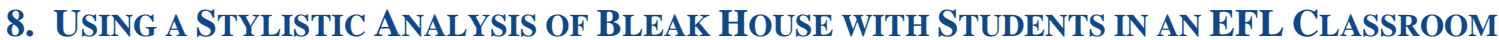

How might a stylistic analysis of this passage be used in an EFL setting? There are many options, but a worksheet designed to lead students through the text, guiding them to discover the lexical, phonological, grammatical, and discourse features of the passage would be a useful component. Duff and Maley (2007) list some useful types of activities that might be included in classroom materials for stylistic analysis. They include reconstruction (learners have to reconstruct the text from jumbled sentences or guess the whole from a part of it presented to them); replacement (students replace parts of the original with items of their own, which can expand learners range of language use); ranking; comparison/contrast; and analysis. Tomlinson (1986) has some practical suggestions that are still useful today for mixed level classes.

See Appendix A for an example worksheet I designed for a stylistic analysis of Bleak House. It starts with students reading through the passage for the overall meaning without doing a close analysis. They answer a few simple comprehension questions as they read. Then it gives very specific tasks to focus their attention on prominent linguistic features that contribute to the overall effect of the passage. The completion of these individual tasks results in a stylistic analysis which includes all four major levels of classic practical stylistics: discourse, grammar, lexis, and phonology. Finally, learners are asked why they think the author wrote the passage and if they themselves enjoyed it, and if they thought it was an example of great literature.

\section{CONCLusion}

Stylistics is not just a fruitful companion to traditional literary analysis, adding a layer of linguistic analysis to the usual components of criticism and analysis. It is a vehicle for exploring that which sets literature apart from prose-its language. It is beneficial not only to native speakers encountering a work in their own tongue but also to second language learners experiencing a work in their chosen language of study. Though there are some critics who claim that stylistic analysis does not especially help, and can even harm learners (Gower 1986), such asseverations do not hold up - especially for EFL students who are often not privy to the historical cultural context of a particular work (with all its complex allusions and references). Stylistics can be a way for these students to benefit from the text in the absence of being part of the discourse community of native speakers of the language the text was written in. 


\section{REFERENCES}

[1] Amir, S. (2018). Stylistic Analysis of the Short Story "The Tell-Tale Heart" by Edgar Allan Poe. Angloamericanae Journal, 3:1, 18-28.

[2] Bloemert J., Paran A., Jansen E., van de Grift W. (2019) Students' perspective on the benefits of EFL literature education. Language Learning Journal 47 (3), 371-384.

[3] Calafato, R., Paran A. (2019) Age as a factor in Russian EFL teacher attitudes towards literature in language education. Teacher and teacher education 79, 28-37.

[4] Carter, Ronald. (2010) Methodologies for Stylistic Analysis: practices and pedagogies. https://teachgrammar.com/wp-content/uploads/2012/07/2010+-Grammar-and-Stylistics.pdf. Accessed 21 Aug. 2019

[5] Celce-Murcia, M. (2002). What it makes sense to teach grammar through context and through discourse. In E. Hinkel \& S. Fotos Eds., New perspectives on grammar teaching in second language classrooms (119-134). Mahwah, NJ: Lawrence Erlbaum.

[6] Dickens, C. (2003). Bleak house. London, UK: Penguin. (Original work published 1852-1853)

[7] Duff, A. \& Maley, A. (2007). Literature (Resource Books for Teachers) (2nd ed.). Oxford, UK: Oxford University Press.

[8] Ellis, R. (2003). Task-based Language Learning and Teaching. New York, NY: Oxford.

[9] Ellis, R. (2005). Principles of Instructed Language Learning. Asian EFL Journal, 7:3, 1-16.

[10] Gower, R. (1986). Can stylistic analysis help the EFL learner to read literature? ELT Journal, 40:2, 125-130.

[11] Hull, T. (2019). Activating passive vocabulary and using it with increased fluency. International Journal on Studies in English Language and Literature 7 (9), 19-23.

[12] Kellem, H. (2009). The Formeaning Response Approach: Poetry in the EFL Classroom. English Teaching Forum 47 (4), 12-17.

[13] Krashen, S. (1982). Principles and practice in second language acquisition. New York: Pergamon Press.

[14] Nation. P. (2013). Learning vocabulary in another language (2 ${ }^{\text {nd }}$ ed.). Cambridge, UK. Cambridge University Press.

[15] Nation. P. (2014). What do you need to know to learn a foreign language? St. Petersburg, FL. Compass Publishing.

[16] Paran, A; Robinson, P.C. (2016). Bringing literature into the classroom. Oxford, UK: Oxford University Press

[17] Rosenkjar, P. (2006). Learning and teaching how a poem means: Literary stylistics for EFL under graduates and language teachers in Japan. In A. Paran, ed., Literature in language teaching and learning. Alexandria, VA: TESOL.

[18] Sinclair, J. (1982). The integration of language and literature in the English curriculum. In R. Carter \& D. Burton Eds., Literary text and language study (9-26). London, UK: Edward Arnold.

[19] Tomlinson, B. (1986). Using poetry with mixed ability language classes. ELT Journal, 40:1, 33-41.

[20] Widdowson, H. (1975). Stylistics and the Teaching of Literature. London, UK: Routledge.

[21] Widdowson, H. (1992). Practical Stylistics. Oxford, UK: Oxford University Press.

[22] Widdowson, H. (1972). Stylistic analysis and literary interpretation. In F. Whitehead Ed., Use of English (28-33). London, UK: Hart-Davis Educational.

[23] Zapruder, M. (2019). Interviewed by C.S. Soong. In Against the Grain, KPFA, September 4.

[24] Zapruder, M. (2017). Why Poetry. New York, NY: Ecco.

\section{APPENDIX A}

Stylistic analysis worksheet for an EFL literature class

\section{The opening of Charles Dickens' Bleak House}

A. Read the passage and answer these questions True or False.

1. _ _ The king was sitting in Lincoln's Inn Hall.

2. The dogs, horses, and people are experiencing good conditions.

3. There is fog only in the sky.

4. The gas lights in the shops were lit two hours early because of the fog.

5. The Temple Bar is where the bad conditions are at their worst.

6. The author probably has a positive opinion of the Lord Chancellor. 


\section{Discourse}

B. Look at the first three paragraphs. Can you think of a one-word "theme" for each one? Why did you choose those words for the themes?

\begin{tabular}{|l|l|}
\hline Paragraph & "Theme" \\
\hline 1 & \\
\hline 2 & \\
\hline 3 & \\
\hline
\end{tabular}

C. Each of the first three paragraphs follows a topic-modification structure (there is a topic and then that topic is modified and expanded upon). Do sentences within each paragraph have a similar structure? If so, how would you describe it?

\section{Grammar}

D. In the first paragraph, underline the finite verbs and circle the non-finite verbs. Are there more finite verbs or non-finite verbs? Or vice versa? The same pattern holds for the second and third paragraphs as well. How do you think that affects the overall feeling of the passage?

\section{Lexis}

E. What kind of impression of the city does the author give in describing it with the words 'waddling', 'splashed', 'jostling', 'slipping', and 'sliding'?

F. Now go through the passage and put brackets [] around any words that are repeated. Why might these words be repeated? What effect does it have?

\section{Phonology}

G. Are there any instances of alliteration, assonance, or consonance? How do they contribute to the atmosphere portrayed in the passage?

\section{General Impressions}

H. Now look again at the title of the novel. Why do you think the author might have used this title?

I. Finally, can you guess what some themes of the entire novel might be just by reading the opening passage? Did you enjoy it? Do you think this passage deserves to be called an example of great literature? Why or why not?

Citation: Todd Hull. Stylistic Analysis for the EFL Classroom. "International Journal on Studies in English Language and Literature (IJSELL), vol 7, no. 10, 2019, pp. 28-34. doi: http://dx.doi.org/10.20431/23473134.0710004.

Copyright: () 2019 Authors. This is an open-access article distributed under the terms of the Creative Commons Attribution License, which permits unrestricted use, distribution, and reproduction in any medium, provided the original author and source are credited. 